УДК $78.05+786.8$

\title{
I. Epaiєв
}

\section{ТВОРЧА АРТИСТИЧНО-ТЕАТРАЛЬНА КОНЦЕПЦІЯ СУЧАСНОГО МИСТЕЦТВА «МОДЕРН-БАЯНА»}

\begin{abstract}
У статті викладена теоретична концепція мистецтва українського «модерн-баяна», в якій акцентовані творчі, артистичні та театральні показники як іманентні складові інструментальної гри - принципово головні ремарки сучасного виконавського мистецтва. Великий потенціал удосконалення художньо-виконавської техніки музикантів-інструменталістів, на думку автора, полягає в камерному сегменті мистецтва «модерн-баяна», що актуалізує особистість музиканта-актора - твория, який органічно вписується в ареал «інструментального театру», артистично-театральну парадигму сучасної культури.
\end{abstract}

Ключові слова: артистизм, виконавець-актор, виконавець-новатор, виконавська творчість, модерн-акордеон (баян), модерн-інтонування, нова музика, постмодернізм, психосемантика, театралізація.

Як відомо широкому колу композиторів, виконавців, мистецтвознавців, 90-ті роки XX століття - початок XXI століття були позначені бурхливим розвитком і становленням «нового явища в баянноакордеонному мистецтві - «модерн-акордеон» (термін I. Єргієва)» $[4$, с. 65] в якості нової концепції гри на інструменті (баяні, акордеоні), що склалася в паралелі вітчизняної та зарубіжної творчості видатних виконавців-митців в комплексі з відповідним стилем композиторської творчості.

Вказана концепція мистецтва модерн-баянної гри як вітчизняної версії світового нового акордеонного мистецтва професійних виконавців-митців другої половини ХХ століття полягає в єдності виконавсько-композиторської ініціативи у складенні оригінальних високохудожніх композицій для баяна як «музики для слухання» 3 включенням тембро-сонорних ефектів у функції конкретно-графічних показників - носіїв архетипових смислів музики поставангардного стилю.

Передумовою народження нового напрямку в українському музичному мистецтві став розквіт «високого модернізму» у світовому мистецтві у другій половині XX століття, який відрізнявся рішучими радикальними inventio, тяжінням до стильової новизни, пошуками нового «тембро-сонору» (в тому числі електронного), видовищності, апологією нової естетики «конкретної» музики» (П. Шеффер), на-

(C) Ергієв I., 2014 
маганням втілити нове уявлення про Всесвіт, нові художньо-образні сфери: абстракційного, ірреального, віртуального з орієнтацією на експеримент, видове трансформування, що взагалі є притаманним великому «Просвітницькому проекту».

Розвитку і становленню світового мистецтва модерн-акордеона 3 кінця 60-тих років минулого століття сприяли професійні та культурологічні тенденції епохи постмодернізму: звернення до чіткої «знаковості» мікроелементів виразності («інтонацій-образів», за Б. Асаф’євим), «змішаний стиль» та «змішаний жанр» (М. Лобанова), «плюралістичний метод» (Б. Циммерман), «медитативність» 3 іiі тяжінням до духовно-прикладного значення музичної виразності (О. Маркова), «емансипація консонансу» (О. Маркова, О. Козаренко), «мінімалізм» (К. Поуттер і Е. Стрікленд), «діатонічність мінімалізму» (Д. Дувірак), театр абсурду (С. Беккет), «кельтський ренесанс» (Т. Лірі), потужні хвилі рок- і поп-музики, а також такі «ремарки» даної епохи, як: деконструкція, іронічність, тотальна візуалізація, комунікативність, перформанс, ін.

В ряді факторів, що сприяли народженню феномена світового модерн-акордеона, перш за все виділяється виконавський в якості творчої ініціативи піонерів модерн-акордеонного мистецтва, які виступили «детермінантами» створення акордеонної авангардної музики композитрами-симфоністами «першого ряду».

Харизматичність, рушійна творча діяльність особистостей - виконавців-модерн-акордеоністів в епоху тотальної глобалізації світової культури відрізнялась самопожертвуванням і відреченням в ім'я перетворення акордеона (баяна) - одного з останніх акустичних винаходів XX століття з «instrument from the street» («інструмента з вулиці») в «instrument of high art» («інструмент високого мистецтва», за виразом видатного німецького композитора Г. Катцера), з метою довершення кола академізації акордеонно-баянного виконавського мистецтва засобами нової музики.

Практика діяльності видатних сучасних композиторів-митців, таких як Ю. Такахаші (Японія), А. Нордхейм (Норвегія), Г. Катцер, I. Юн, В. Дінеску (Німеччина), С. Губайдуліна, Е. Дєнісов (Росія), Є. Станкович, О. Щетинський, К. Цепколенко, Л. Самодаєва, (Україна), ін., показала, що їх спосіб написання для акордеона (баяна) базується на фактурно-сонорних пропозиціях виконавців-новаторів. Це були не тільки адресати бажаних виконавських рішень, а й певні співавтори, оскільки традиційна композиторська освіта базувалася 
і базується до цього часу на знаннях інструментів іншого роду, ніж акордеон (баян), і на традиційній композиторській риториці.

Нові прийоми гри - виражальні знахідки-inventio видатних акордеоністів (баяністів) світу: М. Елегарда, А. П'яццолли, М. Рантанена, Ф. Ліпса, Ш. Хуссонга, Т. Анцелотті, А. Меліхара, ін., а також автора даної статті були не просто «включені» в твори композиторів, а й склали цілком визначене «стрижньове» утворення, навколо якого нарощувалося художнє ціле як єдина смислова система.

Так, С. Губайдуліна, яка із захопленням називала баян «чудовиськом, яке дихає», взяла на озброєння перш за все прийоми, які їй продемонстрував Ф. Ліпс: гра повітрям і кластер, що не тільки утворили оригінальний смисловий епіцентр виразності баяна в багатьох іiї твоpax, а й згодом стали ознаками їі стилю в даному жанрі.

Початком відліку нового акордеонно-баянного мистецтва вважається датська співдружність-тандем: баяніст-новатор М. Елегард $\rightarrow$ композитор-неоавангардист позабаянного кола О. Шмідт, хоча перші спроби упровадження акордеона у велике «серйозне» мистецтво були здійснені ще до того А. Бергом, П. Хіндемітом, С. Прокоф'євим у 20-30-ті роки XX століття.

Завдяки особистим ініціативам виконавців - піонерів мистецтва «модерн-баяна» та аурі творчої свободи постмодерністського простору цей феномен мав розповсюдження в країнах Скандинавії, Європи, Америки, Росії, Японії, насамкінець, в Україні. Багато з цих видатних виконавців виступили детермінантами не тільки появи творів у новій стилістиці, а й сприяли розвитку і становленню нових стилів виконавства, що мали коріння в імпровізації, перформансі, театрі.

Точкою відліку нового напрямку в українському мистецтві вважаємо появу на початку 1990-х років експериментального авангардного твору К. Цепколенко «Той, що виходить з кола» у стилістиці нової музики, детермінованого і, головне, презентованого в новій для академічного жанру виконавській манері саме українським виконавцем (автором статті).

Декілька алеаторичних епізодів композиції потребують наявності імпровізаційної обдарованості виконавця i, таким чином, мають статус елітарної винятковості виконавства. У своїх наступних баянних творах, за словами самої композиторки, вона відмовляється від настанов на надскладні виконавські завдання (імпровізацію, комбінаторику) і робить ставку на ретельний нотний запис, що, з одного боку, звузило межі виконавської інтерпретації, але з іншого, - дало 
можливість дещо розширити коло виконавців від елітарного до більш масового.

Нові засоби виразності, що склалися в співтворчій роботі виконавця (автора статті) і композиторки-симфоністки, спрямовані на реалізацію нових для української баянної музики художньо-образних обріїв, вимагають від виконавця не тільки досконалої психотехніки, неабиякої інтуїції, а й нової сценічно-інтонаційної техніки, в тому числі в аспекті зовнішнього втілення-представлення.

Тут доречним є акцент на понятті «модерн-інтонування» яК на новому творчому аспекті виразності гри на баяні (акордеоні), суть якого полягає у відтворенні поряд з інтервально-звуковисотною (класичною) логікою музики нових ритмо-тембральних, динамічно-агогічних перетворень, що складають сутність втілення «ігрових фігур» у звуковеденні, де ембріоном-стрижнем виразності може стати навіть один тон, кластер, сонорний ефект (ікт).

Модерн-інтонування як явище витонченого психологізму, що полягає в людському виконавському одухотворенні конструктивної мікроструктури композицій сучасних авторів, скероване виконавцем на художньо-артистичне відтворення нових змістів нової музики.

На це вказує В. Князєв, аналізуючи твір К. Цепколенко «Той, що виходить 3 кола», як приклад «... відображення специфічного комплексу інтонаційно-виконавських завдань музики постмодерну... витонченої виконавської психотехніки артиста, що грунтується на модифікуючому характері емоцій концертанта в контексті зі смисловим навантаженням музики, що виконується» (курсив наш. - I. Є.) [3, с. 13].

«Витончена психотехніка» виконавця, націлена на відтворення нових образних шарів нової музики й стає підгрунтям для артистизму 3 кінцевим виходом на психосемантику, без якої, як пише А. Самойленко, «нічого не відбудеться - ні з сприймаючим суб'єктом, ні $з$ запропонованою йому знаковою «зовнішністю» смислу, тобто акт комунікації не відбудеться, значення не знайде свій шлях від смислу до знаку» (а також від адресанта-виконавця до адресата-публіки. - I. $E$.) [5, c. 25].

М. Черепанін до цього додає, що «у цьому контексті переосмислюється значення самого інструмента як «акустичного синтезатора», здатного до «мікро- і макроінтонаційних» звукових відтворень, притаманних мистецтву абстракціонізму» [7, с. 130].

Розвитку мистецтва «модерн-баяна» в Україні сприяла як особистість автора даної статті, який ініціював появу численних творів укра- 
їнських композиторів-симфоністів: Є. Станковича, К. Цепколенко, Л. Самодаєвої, О. Щетинського, Ю. Гомельської, А. Томльонової, В. Ларчикова, В. Рунчака, ін. та зарубіжних: Й. Тамульоніса, В. Германавічуса (Литва), Рауль Де Шмета (Бельгія), Якоб тер Вельдгюйса (Голандія), С. Беринського, М. Броннера, Р. Калімулліна (Росія), В. Дінеску (Німеччина) М. Вірсаладзе (Грузія), ін. у стилістиці нової музики у самих різноманітних жанрах (від соло-соліссімо, перформанса, камерно-інструментального до оркестрового та оперного), так і діяльність деяких інших виконавців світового рівня, зокрема заслужених артистів України П. Фенюка та В. Мурзи у співавторстві 3 відомими українськими композиторами В. Рунчаком та В. Власовим, а також виконавців молодої генерації, зокрема А. Дубія, Р. Юсипея у співдружності з київськими композиторами-симфоністами: А. Загайкевич, Г. Гаврилець, С. Пілютиковим, В. Польовою, ін.

Модерн-акордеоніст, спочатку детермінуючи композитора-симфоніста на створення нових композицій за замовленням, а потім й відтворюючи виконавські еталони цих творів в якості світових прем'єр, виявляє саме твориі складові художньої діяльності виконавця-митця.

Окрім сольних творів, ініційованих названими виконавиями-новаторами, великий пласт у новому мистецтві склали й камерні твори за участю баяна українських композиторів-симфоністів, що віддзеркалюють певні жанрові зрушення, спрямовані на видові трансформації, суттєво розширюючи вражаючу «географічну мапу» світового камерно-акордеонного мистецтва за останні півстоліття.

Після перших спроб А. Берга, П. Хіндеміта та С. Прокоф’єва найбільш значними тут є досягнення композиторів світового масштабу: А. Пьяццоли (Аргентина), Дж. Кейджа (США); I. Юна, Г. Катцера, М. Кагеля, (Німеччина); Я. тер Вельдгюйса, Т. Де Марец Оуінз (Нідерланди); А. Нордхейма (Норвегія); Р. Де Смета, Ж. Фонтін (Бельгія); Й. Тамульоніса, В. Германавічуса (Литва); С. Губайдуліної, С. Беринського, М. Броннера (Росія); М. Вірсаладзе (Грузія), Є. Станковича, О. Щетинського, Л. Самодаєвої, В. Зубицького, К. Цепколенко, Ю. Гомельської, А. Томльонової (Україна), ін.

Саме у камерній музиці акордеон (баян) суттєво розширює свої жанрово-стильові образно-художні можливості. Так, маємо виходи: на неокласицизм («Per musica ad astra» Й. Тамульоніса; присвячено дуету «Каданс»: О. Єргієва - скрипка, баян, І. Ергєів - баян), на неоімпресіонізм («Морський пейзаж» С. Беринського, присв. дуету 
«Каданс»), на квазісеріальність і медитативність («Together» О. Щетинського, написаний для дуету «Каданс»), на неофольклор з використанням східних ладових побудов, імпровізаційності викладення музичного матеріалу («Татарський танок» С. Губайдуліної для баяна та двох контрабасів; «Insight» Р. Калімулліна для скрипки, баяна та ударних; «Дитяча сюїта» Л. Самодаєвої, «Lun Y» В. Дінеску для скрипки та баяна), на експресіонізм («Дуель-Дует № 5» К. Цепколенко, останні чотири твори присвячені дуету «Каданс»), ін.

Таке розмаїття композиторських технік-стилів суттєво розширило артистичну техніку виконавців до театральної.

Так, наприклад, «Дитяча сюїта» Л. Самодаєвої, що по суті являє собою відібрані автором статті номери з музики до театральної вистави «По щучому велінню», вимагають наявності саме техніки виконавської «театралізації», що включає: артистичний діалог між виконавцями, комунікативне спілкування з глядачем-слухачем, костюмування, акторське перевтілення виконавців в образи вистави, гра стоячи, локомоції, елементи хореографії...

Твір М. Броннера (Росія, Москва) «Адам і Сва», написаний і присвячений дуету «Каданс», розрахований на гру інструменталістів-акторів: Адама (баяна) і Єви (скрипки), коли виконавці спочатку грають спиною один до одного, потім обличчям у зал i, насамкінець, обличчям один до одного, втілюючи народження почуття любові, демонструє збіг творчих позицій композитора і виконавців: «впливати музикою через образ, пов'язаний з моментом внутрішньої театралізацї». Композитор вважає театральність у сучасному виконавстві обов'язковою. Виконавство-гра для нього - це «театр - прямий або побічний». Слухач, на його думку, повинен находитися «при деякому дійстві» (курсив наш. - I. E.) [2, с. 25].

В підсумку констатуємо великий потенціал удосконалення художньо-виконавської техніки баяністів-акордеоністів завдяки камерному сегменту мистецтва «модерн-баяна». Останній актуалізує проблему виховання сучасного акордеоніста-актора, який органічно вписується в загальну артистично-театральну парадигму сучасної музичної культури, що охоплює й альтернативні напрямки музики: рок, фьюжн, поп, діджей, ін.

Відтак, сучасне інструментально-виконавське мистецтво, залучаючи «різноманітні ансамблеві поєднання із класичними інструментами, синтетичні сполучення із відеорядом, електронікою» [4, с. 65], в тому числі й завдяки мистецтву модерн-баяна повертається на но- 
вому колі мистецької «спіралі» до архетипів синкретичної органіки обрядової культури, коли змістовність інструментальної гри посилюється видовищністю дійства «інструментального театру» завдяки розмові, співу, руху, танцю, ін.

Як вказує В. Князєв, «візуалізація-театралізація баяніста» відбувається «...не тільки за рахунок яскравого відтворення специфічних відеопластичних показників, а й як відображення нової образності... Новий контекст сценічної діяльності вимагає переосмислення та вдосконалення артистично-театральних аспектів виконавської техніки баяніста, адже сучасна концепція виконавської техніки баяніста передбачає віртуозне володіння ... не тільки всією палітрою технічновиражальних засобів інструментальної виразності, але й наявністю цілого комплексу якостей акторської майстерності» (курсив наш. I. E.) [там же].

Процес розвитку і становлення українського «модерн-баяна» значно прискорив фестивальний рух 90 -х років минулого століття на тлі демократизації українського суспільства. Ініційовані композиторами-небаяністами фестивалі (зокрема, К. Цепколенко - «Два дні і дві ночі нової музики»), не тільки сприяли зміцненню нової гілки в українському мистецтві, а й стали діючою платформою демонстрації нових артистично-театральних версій-рішень у сценічному представленні модерн-баянної гри, стимулювали формування нової $\boldsymbol{x y}$ дожньо-виконавської техніки для всього академічного виконавства, спрямованої не тільки на втілення внутрішнього переживання новоі духовності (нових образних сфер) новими сонорними засобами виразності (в тому числі й авторсько-виконавськими), а й на візуалізацію, видовищність, дійство, неординарні, іноді «позаакадемічні» сценічні рішення.

«Галерея» видатних модерн-баяністів і акордеоністів світу (Г. Нот, М. Елегард, М. Рантанен, Е. Мозер, С. Хуссонг, М. Керн, А. Меліхар, Ф. Ліпс, О. Шаров, М. Мікі, Ю. Гуревич, ін.) та їх новаторська діяльність дають підставу для підведення підсумків у вигляді узагальненої характеристики «модерн-акордеоніста» як митця-особистості:

- настановлення на новаторство у творчості як основний чинник гри;

- системна співпраця з сучасними композиторами, їх творча детермінація, коли замість звичного ланцюжка - «від композитора» виникає складний тип «прямого і зворотного» шляху відносин виконавця та композитора, що готують світові прем’єри; 
- творча вибудова нових синтезів-жанрів, у тому числі інсталяцій, перформансів, хореографії, ін.;

- утвердження акордеона/баяна як сольного академічного інструмента в концертах із камерним, духовим, симфонічним оркестрами;

- естетичне удосконалення сценічної художньої техніки у напрямку театралізації.

Завдяки спільним зусиллям композиторів С. Станковича, В. Власова, О. Щетинського, К. Цепколенко, Л. Самодаєвої, В. Рунчака, А. Томльонової, А. Загайкевич, В. Польової, Г. Гаврилець, С. Зажитько, ін. та діяльності провідних українських виконавців П. Фенюка, А. Дубія, Р. Юсипея, В. Мурзи, І. Сргієва виникають нові еволюційно-мистецькі завоювання українського «модерн-баяна» як самодостатньої і оригінальної паралелі до скандинавських, латиноамериканських, німецьких, польських, французьких, італійських, іспанських, американських, інших національних феноменів мистецтва модернакордеона, дещо окремо по відношенню до української оригінальної музики 1970-1980-х років за позиціями:

- застосування сонорно-алеаторної гри;

- опозиції «баянному соцреалізму» 1950-1980-х років;

- тяжіння до змістовного, глибинно-духовного значення акордеонного мистецтва;

- становлення українських камерно-баянних жанрів;

- розширення образної сфери оригінальної акордеонної музики в бік абстракції, віртуальної реальності, еклектики поєднання реальних та ірреальних сфер у смилових образах-вираженнях;

- долання стильової обмеженості акордеонної музики: неокласицизм у творах А. Томльонової, В. Рунчака, В. Ларчикова; постмодернізм у квазісеріальному та медитативному вираженні О. Щетинського; експресіонізм у творах Л. Самодаєвої, К. Цепколенко, Ю. Гомельської, ін.

Камерно-баянний жанр стає чи не вирішальним фактором входження українського баяна в «цивілізовану» сім'ю світових академічних інструментів завдяки накопиченню оригінального репертуару.

За словами А. Сташевського, «переважна більшість камерно-інструментальних опусів із залученням баяна створена одеськими композиторами для виконавця і пропагандиста сучасної баянної музики Івана Єргієва, який вдало поєднує як сольну творчість, так і ансамблеву (передусім в дуеті «Каданс», а також в різних інструментальних складах)» $[6$, с. 22]. 
На думку доктора мистецтвознавства М. Черепаніна, модернакордеон як феномен, «суть якого полягає в еволюції акордеонного виконавства в напрямку винятково «нової» оригінальної музики, «нових» композиторів і відповідно «нових» виконавців та їхній співпраці з творцями цієї музики (П. Фенюк - В. Рунчак, В. Мурза - В. Власов, І. Єргієв - К. Цепколенко, Л. Самодаєва, Ю. Гомельська)» став «... новим відгалуженням в українському мистецтві» [7, с. 130], а «пропаганда ... сучасної («нової») музики стала однією з визначальних рис Одеської акордеонно-баянної школи, яка заявляє про значні досягнення не тільки у вузьковиконавському плані, але й в основоположних аспектах професійної освіти» (курсив наш. I. E.) [7, c. 135].

Таким чином, викладена теоретична концепція сучасного мистецтва модерн-баяна узагальнює практичний «рівень виконавської майстерності провідних українських баяністів, віддзеркалює загальну тенденцію в галузі до зростання творчого потенціалу і збагачення артистично-театральних та музично-інтонаційних засобів мистецького впливу» (курсив наш. - I. E.) [1, с. 302].

Для визначення творчого аспекту виконавства модерн-акордеоністів можна вживати поняття продуктивно-прогресивної діяльності, що проявляє себе у світових прем'єрах - артистично-театральних еталонах-інтерпретаціях у якості антитези репродуктивному ремісництву (академічному формалізму - мистецтву «втрачених емоцій»).

\section{СПИСОК ЛІТЕРАТУРИ}

1. Давидов М. А. Виконавське музикознавство : Енциклопедичний довідник / М. А. Давидов. - Луцьк : ВАТ «Волинська обласна друкарня», 2010. $-400 \mathrm{c}$.

2. Интервью М. Б. Броннера О. П. Васильеву. Инструмент невыявленных возможностей // Народник. - М. : Музыка, 2009. - № 2 (66). - С. 23-25.

3. Князєв В. Ф. Еволюція виконавської техніки в українській баянній школі (друга половина XX століття): автореф. дис. ... канд. мистецтв. : 17.00 .03 / Владислав Федорович Князєв ; Нац. муз. акад. України ім. П. І. Чайковського. - К., 2005. - 20 с.

4. Князєв В. Ф. Еволюція виконавської техніки в українській баянній школі (друга половина XX ст.) / В. Ф. Князєв // Львівська баянна школа та iіi видатні представники : зб. матер. наук.-практ. конф. - Дрогобич : Коло, 2005. - C. 59-66.

5. Самойленко А. И. «Язык сознания» и семантический анализ музыки: к постановке проблемы / А. И. Самойленко // Музичне мистецтво і культура : 
Науковий вісник Одеської державної музичної академії імені А. В. Нежданової / [гол. ред. О. В. Сокол]. - Одеса : Друк, 2004. - Кн. 2, вип. 4. - С. 18-29.

6. Сташевский А. Я. Панорама украинского баянного авангарда на рубеже столетий / А. Я. Сташевский // Народник. - М. : Музыка, 2006. - № 2 (54). - C. 20-23.

7. Черепанін М. Естрадний олімп акордеона : монографія / М. В. Черепанін, М. В. Булда. - Івано-Франківськ : Лілея-НВ, 2008. - 256 с.

Ергиев И. Твориеская артистически-театральная конщепция современного искусства «модерн-баяна». В статье изложена теоретическая концепция искусства украинского «модерн-баяна», в которой акцентируются творческие, артистические и театральные показатели как имманентные составляющие инструментальной игры - принципиально главные ремарки современного исполнительского искусства. Большой потенциал усовершенствования художественно-исполнительской техники музыканта-инструменталиста, по мнению автора, заключается в камерном сегменте искусства «модерн-баяна», что актуализирует личность музыканта-актера - творца, который органично вписывается в ареал «инструментального театра», артистически-театральную парадигму современной культуры.

Ключевые слова: артистизм, исполнитель-актер, исполнитель-новатор, исполнительское творчество, модерн-аккордеон (баян), модерн-интонирование, новая музыка, постмодернизм, психосемантика, театрализация.

Yergiyev I. Creative, artistic and theatrical concept of the contemporary art of «modern-bayan». The article stated the concept of the art of Ukrainian «modern-bayan», in which creative, artistic and theatrical performance is accented as an inherent component of playing a musical instrument and as the main remark of contemporary performing arts. Great potential to improve artistic and performing techniques of musician-instrumentalist, according to the author, is a chamber segment of the art of «modern-bayan», which actualizes the personality of the musician-actor - the creator, which fits into the area of «instrumental theater», an artistic and theatrical paradigm of modern culture.

Keywords: artist-innovator, artistry, performer-actor, performing creativity, modern-accordion (bayan), modern-intonation, new music, postmodernism, psychosemantics, theatrical adaptation to stage.

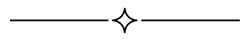

